\title{
SEROPREVALENCE OF Toxoplasma gondii INFECTION AMONG INDIAN PEOPLE LIVING IN IAUARETÉ, SÃO GABRIEL DA CACHOEIRA, AMAZONAS, BRAZIL
}

\begin{abstract}
SUMMARY
The goal of this survey was to estimate the seroprevalence of Toxoplasma gondii infection in Iauareté, a multiethnic Indian community in the upper Rio Negro basin. We carried out a cross-sectional survey $(n=260)$, in order to obtain serum samples and demographic data. The sample was randomly selected, by family conglomerate analysis. Serodiagnosis was performed by an enzyme-linked immunosorbent assay and indirect immunofluorescence. Prevalence of reactivity was 73.5\% (191/260), being higher in the older-age groups, reaching 95.7\% (44/46) in the group aged 50 years or more. The majority of seropositive subjects had titers equal to or less than 1:64. Seroprevalence was greater in Indians belonging to the Hupda ethnic group ( $\mathrm{p}=0.03$ ). According to the present survey, Indian people living in Iauareté have a high prevalence of antibodies to T. gondii. Demographic concentration and urbanization within low sanitation and poor hygiene backgrounds, as well as unfiltered water consumption, may be related to the high frequency of $T$. gondii seroprevalence observed in the studied area.
\end{abstract}

KEYWORDS: Toxoplasma gondii; Prevalence; Indians; Brazilian Amazon; Iauareté.

\section{INTRODUCTION}

The Apicomplexa protozoan Toxoplasma gondii is a human parasite, with an ubiquitous distribution ${ }^{7}$. Prevalence of $T$. gondii infection varies widely, depending on cultural, geographic and climatic factors ${ }^{12}$. More often asymptomatic, $T$. gondii infection may be a severe and lifethreatening disease when it affects the fetus in utero or occurs in immunocompromised hosts ${ }^{1,6}$. In immunocompetent individuals, toxoplasmosis is a major cause of chorioretinitis ${ }^{12}$.

Surveys carried out in order to assess $T$. gondii infection prevalence in Brazilian Indian societies show rates of $39 \%$ to $100 \%{ }^{2,8,10,11,13,14}$. SOBRAL et al. (2005) studied Indians belonging to ethnic groups with different degrees of acculturation. They observed a seroprevalence of 57.3\% for the Tiriyó in the State of Pará, 78.8\% for the EnawenêNawê from Mato Grosso and 57.7\% for the Waiãpi living in Amapá ${ }^{14}$. Authors observed that contact with non-Indians probably do not influence infection prevalence, but differential contact with soilharboring oocysts from wild felines and consumption of infected game meat could be responsible for differences between tribes.

The objective of this study was to estimate the prevalence of infection with $T$. gondii among Indians living in Iauareté, Brazilian Amazonia. Seroprevalence was determined with respect to gender, age group and ethnicity.

\section{POPULATION AND METHODS}

Description of studied population and area: The upper Rio Negro basin (northwest of the Brazilian Amazon) is a multiethnic Indian region, encompassing people belonging to four Amerindian language families, with variable degrees of acculturation and inter-ethnic contact ${ }^{9}$. Iauareté is a small city where near 2,300 Indians live; they belong to ten ethnic groups, in the Uaupés River margins. The Hupda are Indians belonging to the Maku speaking society. They present the lower social strata in Iauareté and, historically, resist accepting acculturation, so they are not integrated in the local economy and have no cash-oriented activities. Hupda Indians living in Iauareté live in a specific district, Vila de Fátima. The other districts are inhabited by Indians belonging to ethnic groups from Tukano Oriental (Tukano, Desana, Kubeo, Tuyuca, Pira-tapuya, Arapaso and Wanana groups) and Aruak (Tariana and Baniwa groups) speaking societies. The demographic concentration observed in Iauareté is the result of Indians' acculturation, carried out by the Catholic Church in the last century, with the arrival of the Franciscans in 1884 and their substitution by the Salesians in $1914^{9}$.

Sampling and statistical analyses: A seroprevalence survey with sampling by conglomerate was performed. One in every eight dwellings was randomly and systematically selected for inclusion in the study. Considering a population of 2,300 subjects, sample size was calculated expecting a seroprevalence of $75 \%$, with a confidence level of $95 \%$ 


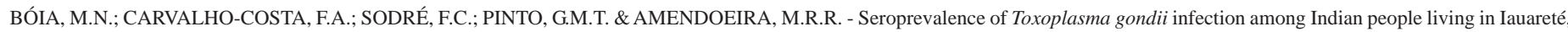
São Gabriel da Cachoeira, Amazonas, Brazil. Rev. Inst. Med. trop. S. Paulo, 50(1): 17-20, 2008.

and an acceptable error of 5\%. Results were presented as descriptive statistics stratified by age, gender and ethnic group. Frequencies were compared through chi-square test at a 5\% significance level. Data were stored and processed on EpiInfo 2000 version 3.3.2.

Collection and processing of samples: Blood samples (approximately $10 \mathrm{~mL}$ ) were collected through the Vacutainer ${ }^{\circledR}$ system by peripheral venipuncture. Sera were stored at $-15^{\circ} \mathrm{C}$ in order to be transported to Rio de Janeiro. Analysis of serum samples was carried out at the FIOCRUZ Toxoplasmosis Laboratory. An enzyme-linked immunosorbent assay (ELISA) was used for detection of IgG antibodies to $T$. gondii $(\mathrm{n}=206)$. The cut-off point for the IgG-ELISA was established by assaying 12 negative standard serum samples and four positive serum samples on four different plates. The cut-off for each plate consisted of the mean reading of the negative serum sample plus two standard deviations. A correction factor was determined by dividing the median of the cut-off value by the average reading value of the negative sera in these plates. An indirect immunofluorescence antibody assay (IIFA) was used for the detection of IgM antibodies and specific IgG antibodies $(\mathrm{n}=148)$. Five different serum dilutions, ranging from $1: 16$ to $1: 4,096$, were prepared in phosphate-buffered saline. For detection, conjugated anti-IgM and anti-IgG human fluorescent antibodies diluted 1:50 were used. This dilution was established after analysis with standard reactive and non-reactive serum. A reaction with a serum dilution $\geq 1: 16$ was considered reactive and the final title was the last dilution that still showed fluorescence in the periphery of the parasites. The fluorescent tests were performed according to CAMARGO (1964) ${ }^{3}$. The material was examined using an epifluorescence microscope (Y-FL; Nikon, Tokyo, Japan) using a 40× objective, a 10× ocular lens, an ND16 exciting filter, and a mercury lamp.

The IIFA assay was standardized in our laboratory and showed comparable sensitivity and specificity as that of the Sabin Feldman dye test, which is regarded as the gold standard. The titers measured by the IIFA assay and the dye test are comparable ${ }^{3,15}$. All serum samples were tested for the presence of the rheumatoid antibodies using a diagnostic kit (Bio Lab Mérieux SA, Rio de Janeiro, Brazil)4 ${ }^{4}$ Serum reactive to $T$. gondii was retested with an immunoenzymatic assay for IgM antibodies (Platelia ${ }^{\circledR}$ Toxoplasma gondii IgM tetramethilbenzidine; Bio-Rad Laboratories, Marnes la Coquette, France).

Ethical guidelines: Subjects were included after informed consent. The research was previously approved by the Human Subject Ethics Committee at Evandro Chagas Research Institute of Oswaldo Cruz Foundation and by the Indian National Foundation (FUNAI).

\section{RESULTS}

Samples were considered positive if any method (i.e., ELISA or IIFA) was reactive. As presented on Table 1, prevalence of positive serology by ELISA or IIFA was 73.5\% (191/260). Frequency of reactivity to one of the tests increased with age, reaching $95.7 \%$ (44D 46) in the group aged 50 years or more. The majority of seroreactive subjects had titers equal to or less than 1:64 (Table 2). Indians belonging to the Hupda ethnic group presented a higher frequency of seropositivity, but this had no statistical significance (Table 3 ). No subject had a positive IgM serological result.
Table 1

Seroprevalence of Toxoplasma gondii antibodies, by enzyme-linked immunosorbent assay (ELISA) or immunofluorescence (IIFA) by age group and gender in Iauareté, São Gabriel da Cachoeira, AM, Brazil, 2001 1,2

\begin{tabular}{lccc}
\hline $\begin{array}{l}\text { Age group } \\
\text { (years) }\end{array}$ & Males & Females & Total \\
\hline$<10$ & $9 / 24(37.5)$ & $8 / 18(44.4)$ & $17 / 42(40.5)$ \\
$10-19$ & $26 / 42(61.9)$ & $29 / 44(65.9)$ & $55 / 86(64)$ \\
$20-29$ & $11 / 14(78.1)$ & $14 / 18(77.8)$ & $25 / 32(78.1)$ \\
$30-39$ & $10 / 11(90.9)$ & $12 / 13(92.3)$ & $22 / 24(91.7)$ \\
$40-49$ & $14 / 15(93.3)$ & $14 / 15(93.3)$ & $28 / 30(93.3)$ \\
$\geq 50$ & $25 / 25(100)$ & $19 / 21(90.5)$ & $44 / 46(95.7)$ \\
Total & $95 / 131(72.5)$ & $96 / 129(74.4)$ & $191 / 260(73.5)$ \\
\hline
\end{tabular}

1- Values are positive/performed examinations (\%); 2- Samples reactive by any method (ELISA or IIFA) were considered positive.

Table 2

IgG titers (IIFA) to Toxoplasma gondii by age group in Iauareté, São Gabriel da Cachoeira, AM, Brazil, 2001 ${ }^{1}$

\begin{tabular}{|c|c|c|c|c|c|}
\hline $\begin{array}{l}\text { Age group } \\
\text { (years) }\end{array}$ & $1: 16$ & $1: 64$ & $\begin{array}{c}\text { Title } \\
1: 256\end{array}$ & $1: 1,024$ & 1:4,096 \\
\hline $\begin{array}{l}<10 \\
\mathrm{n}=13\end{array}$ & 23.1 & 15.4 & 30.8 & 23.1 & 7.7 \\
\hline $\begin{array}{l}10-19 \\
n=42\end{array}$ & 28.6 & 38.1 & 26.2 & 4.8 & 2.4 \\
\hline $\begin{array}{l}20-29 \\
n=20\end{array}$ & 30 & 40 & 30 & - & - \\
\hline $\begin{array}{l}30-39 \\
n=17\end{array}$ & 29.4 & 41.2 & 11.8 & 11.8 & 5.8 \\
\hline $\begin{array}{l}40-49 \\
n=20\end{array}$ & 45 & 40 & 10 & - & 5 \\
\hline $\begin{array}{l}\geq 50 \\
\mathrm{n}=36\end{array}$ & 44.4 & 30.6 & 11.1 & 13.9 & - \\
\hline
\end{tabular}

1- Values are in percentages (\%).

\section{Table 3}

Seroprevalence to Toxoplasma gondii antibodies by ethnic group and gender in Iauareté, São Gabriel da Cachoeira, AM, Brazil, $2001^{1}$

\begin{tabular}{lcc}
\hline \multirow{2}{*}{ Gender } & \multicolumn{2}{c}{ Ethnic group } \\
\hline Male & $10 / 11(90.9)$ & Others \\
Female & $8 / 8(100)$ & $88 / 120(70.8)$ \\
\hline Total & $18 / 19(97.7)^{2}$ & $173 / 241(71.8)^{2}$ \\
\hline $\begin{array}{l}\text { 1- Values are positive/performed examinations (\%); 2- p (chi-square) }=0.03 ; \text { Odds ratio } \\
\text { (OR) = 7.08; 95\% confidence interval (CI) }=0.97-144.9 .\end{array}$
\end{tabular}




\section{DISCUSSION}

According to the present survey, Indian people living in Iauareté have a high prevalence of $T$. gondii. infection.

The effects of acculturation and demographic concentration processes are well documented in relation to the spread of infectious diseases, mainly tuberculosis, malaria and intestinal parasitosis. In Venezuela, the acculturation process raised the prevalence of toxoplasmosis among Indian people, probably due to the beginning of a sedentary lifestyle and demographic concentration, including the presence of domestic animals and increased environmental contamination with domestic cats' excreta ${ }^{5}$.

In our study, although the prevalence of seroreactivity increased with age, reaching $95.7 \%$ in subjects older than 50 years, a high frequency of antibody detection was also observed in the younger age groups. The frequency of infection among subjects aged 10 to 19 years (64\%) points to a high level of transmission of $T$. gondii in the studied area, since people are exposed to infective forms in childhood. Among women aged 10 to 29 years, 66\% presented a reactive serology. This suggests a high risk of congenital transmission of $T$. gondii.

Hunting is still an important activity between Indians living in the region, mainly in seminomad societies, like Maku Hupda. Various species of midsize rodents and monkeys are hunted for food. Ingestion of infective forms through inadequately cooked game meat, as well as handling carcasses of wild game should be considered a potential source of infection in Iauareté. However, it was not observed in the studied area whether meat is well cooked. Filtering of drinking water is not performed by the studied families. The Hupda district in the city presents the worst sanitation status in Iauareté. Positive serologies were more common between these Indians.

Health assistance offered to people living in Iauareté is very deficient. We believe congenital and ocular toxoplasmosis are misdiagnosed in the area. Three of the surveyed subjects were blind, but we did not have an ophthalmologist in the research team to perform an accurate ophthalmic examination. Other eye diseases, like trachoma, are hyperendemic in the upper Rio Negro basin, leading to blindness frequently.

AIDS prevalence is unknown in the studied region, but HIV can potentially spread in the upper Rio Negro basin. Permanent military presence, sexual exploitation of Indian girls, urbanization, poverty and increasing trading for sex are factors that reinforce this possibility. Unfortunately, we did not have authorization to perform HIV testing, so baseline information for future comparisons could not obtained. Neurotoxoplasmosis could become a public health concern in the case of HIV spread in the region.

\section{RESUMO}

\section{Soroprevalência da infecção por Toxoplasma gondii em populações indígenas de Iauareté, São Gabriel da Cachoeira, Amazonas, Brasil}

Este estudo objetivou estimar a soroprevalência da infecção por Toxoplasma gondii em Iauareté, uma comunidade indígena multiétnica situada na bacia do Alto Rio Negro. Foi realizado um estudo seccional ( $n=260$ ), obtendo-se amostras de soro e dados demográficos, através de amostragem sistemática por conglomerado. Os testes sorológicos foram realizados através de ensaio imunoenzimático e imunofluorescência indireta. A prevalência da reatividade foi de 73,5\% (191/260), aumentando com a faixa etária e atingindo 95,7\% (44/46) em maiores de 50 anos. A maioria das amostras reativas apresentou títulos iguais ou inferiores a 1:64. Observou-se maior freqüência de reatividade entre os índios da etnia Maku Hupda. De acordo com o presente estudo, a população indígena de Iauareté apresenta alta prevalência da presença de anticorpos contra T. gondii. A concentração demográfica e a urbanização, conduzidas sem infra-estrutura sanitária, levadas a cabo na região no ultimo século, podem estar relacionadas à alta frequiência de detecção de anticorpos contra $T$. gondii na área estudada.

\section{ACKNOWLEDGEMENTS}

We would like to acknowledge the Non-governmental Organization Saúde Sem Limites (SSL) staff, for essential support in the organization of field activities. We also give special thanks to the Indian people of Iauareté, who nicely received us in their homes, providing information and clinical samples. We would like to thank our colleague Dr. Cristiane Lamas for help in preparing this manuscript.

\section{REFERENCES}

1. AMBROISE-THOMAS, P. \& PELLOUX, H. - Toxoplasmosis, congenital and in immunocompromised patients: a parallel. Parasit. Today, 9: 61-63, 1993.

2. BARUZZI, R.G. - Contribution to the study of the toxoplasmosis epidemiology. Serologic survey among the Indians of the Upper Xingu River, Central Brazil. Rev. Inst. Med. trop. S. Paulo, 12: 92-104, 1970.

3. CAMARGO, M.E. - Improved technique of indirect immunofluorescence for serological diagnosis of toxoplasmosis. Rev. Inst. Med. trop. S. Paulo, 6: 117-118, 1964.

4. CAMARGO, M.E.; LESER, P.G. \& LESER, W.S. - Diagnostic information from serological tests in human toxoplasmosis. I. A comparative study of hemagglutination, complement fixation, IgG- and IgM-immunofluorescence tests in 3,752 serum samples. Rev. Inst. Med. trop. S. Paulo, 18: 215-226, 1976.

5. CHACIN-BONILLA, L.; SANCHEZ-CHAVES, Y.; MONSALVE, F. \& ESTEVEZ, J. Seroepidemiology of toxoplasmosis in Amerindians from western Venezuela. Amer. J. trop. Med. Hyg., 65: 131-135, 2001.

6. DESMONTS, G. \& COUVREUR, J. - Congenital toxoplasmosis: a prospective study of 378 pregnancies. New Engl. J. Med., 290: 1110-1116, 1974.

7. DUBEY, J.P. - Toxoplasma, Neospora, Sarcocystis and other tissue cyst-forming coccidia of human and animals. In: KRIER, J.P., ed. Parasitic Protozoa. San Diego, Academic Press, 1993. p. 1-157.

8. FERRARONI, J.J. \& LACAZ, C.S. - Prevalência de anticorpos contra os agentes causadores da hepatite, malária, sífilis e toxoplasmose em cinco populações. Rev. Inst. Med. trop. S. Paulo, 24: 155-161, 1982.

9. INSTITUTO SOCIOAMBIENTAL - Povos Indígenas do Brasil, Noroeste Amazônico. http://www.socioambiental.org. Accessed 10/11/2005.

10. LESER, P.G.; CAMARGO, M.E. \& BARUZZI, R. - Toxoplasmosis serologic tests in Brazilian Indians (Kren-Akorore) of recent contact with civilized man. Rev. Inst. Med. trop. S. Paulo, 19: 232-236, 1977. 
BÓIA, M.N.; CARVALHO-COSTA, F.A.; SODRÉ, F.C.; PINTO, G.M.T. \& AMENDOEIRA, M.R.R. - Seroprevalence of Toxoplasma gondii infection among Indian people living in Iauareté, São Gabriel da Cachoeira, Amazonas, Brazil. Rev. Inst. Med. trop. S. Paulo, 50(1): 17-20, 2008.

11. LOVELACE, J.K. MORAES, M.A.P. \& HAGERBY, E. - Toxoplasmosis among the Ticuna Indians in the state of Amazonas, Brazil. Trop. geogr. Med., 30: 295-300, 1978.

12. MELAMED, J.; SEBBEN, J.C.; MAESTRI, M.; SILVEIRA, S. \& LOCATELLI, C. Epidemiology of ocular toxoplasmosis in Rio Grande do Sul, Brazil. In: DERNOUCHAMPS, J.P.; VEROUGSTRAETE, L.; CASPER-VELU, L. \& TASSINGNON, M.J., ed. Recent advances in uveitis. Brussels, Proceedings of the Third International Symposium on Uveitis, 1992. p. 211-214.

13. NEEL, J.V.; ANDRADE, A.H.P.; BROWN, G.E. et al. - Further studies of the Xavante Indians. IX. Immunologic status with respect to various diseases and organisms. Amer. J. trop. Med. Hyg., 17: 486-498, 1968.
14. SOBRAL, C.A.; AMENDOEIRA, M.R.R.; TEVA, A.; PATEL, B.N. \& KLEIN, C.H. Seroprevalence of infection with Toxoplasma gondii in indigenous Brazilian populations. Amer. J. trop. Med. Hyg., 72: 37-41, 2005.

15. WONG, S.Y. \& REMINGTON, J.S. - Toxoplasmosis in pregnancy. Clin. infect. Dis., 18: 853-861, 1994.

Received: 24 May 2007

Accepted: 26 October 2007 